\title{
The Business Cycle, Inflation, and Unemployment Rate Nexus: An Empirical Approach
}

\author{
Tito Belchior Silva Moreira ${ }^{1}$, Michel Constantino ${ }^{2}$, George Henrique de Moura Cunha ${ }^{3}$ Paulo Roberto Pires de \\ Sousa $^{4} \&$ Luciano Balbino dos Santos ${ }^{5}$ \\ ${ }^{1}$ Economics Department, Universidade Católica de Brasília (UCB), Brasília-DF, Brazil \\ ${ }^{2}$ Programas de Doutorado em Ciências Ambientais e Sustentabilidade Agropecuária e em Desenvolvimento \\ Local, Universidade Católica Dom Bosco (UCDB), Campo Grande, MS, Brazil \\ ${ }^{3}$ Programa de Pós-graduação em Desenvolvimento Regional do Centro Universitário Alves Faria, Goiania,GO, \\ Brazil \\ ${ }^{4}$ Departamento de Ciencias Sociais, Universidade Federal do Amazonas (UFAM), Manaus, AM, Brazil \\ ${ }^{5}$ Departamento de Ciencias Sociais, Universidade do Estado do Amazonas (UEA), Manaus, AM, Brazil \\ Correspondence: Tito Belchior Silva Moreira, Economics Department, Universidade Católica de Brasília (UCB), \\ Brasília-DF, Brazil. Tel: 61-3264-4787. E-mail: titoeco@yahoo.com.br
}

Received: July 24, 2021

doi:10.5539/ijef.v13n10p110
Accepted: September 4, 2021

Online Published: September 12, 2021

URL: https://doi.org/10.5539/ijef.v13n10p110

\begin{abstract}
This paper revisits the main assumption regarding the original Phillips curve regarding the American economy, in which one assumes that the unemployment rate causes an inflation rate. In this context, this paper aims to evaluate if the variance of the inflation rate affects the unemployment rate and, besides, if there is a one-way causality from the variance of the inflation rate to the unemployment rate. Based on quarterly time series from 1959:04 to 2019:04 the empirical results show, via OLS and GMM methods, that the monetary policy affects the business cycle, and, in turn, the business cycle impacts the unemployment rate. Hence, the monetary policy affects indirectly the unemployment rate via the business cycle. On the other hand, the variance of the inflation rate contributes to an increase in the unemployment rate, consequently, there isn't a trade-off between the unemployment rate and the variance of the inflation rate. Moreover, there is a one-way causality from the variance of the inflation rate to the unemployment rate. This is the contribution of this paper. At last, based on the Phillips curve, one expects that the unemployment rate causes the inflation rate. However, the Granger causality tests display a two-way causality relation between both variables.
\end{abstract}

Keywords: Phillips's curve, variance of inflation rate, unemployment rate, Granger causality, business cycle

\section{Introduction}

Phillips (1958) showed that there is a negative correlation between the unemployment rate and the rate of change in money wage rates from 1861 and 1957 in the United Kingdom. Considering that the inflation rate and variation of nominal wages tend to move together, Samuelson and Solow (1960) confirmed the negative correlation between the unemployment rate and inflation rate in the US. According to them, this correlation emerged because low unemployment rates are associated with high aggregate demand that, in turn, contributes to increasing the wage as well as all the prices of the economy.

Friedman (1968) highlights that there is always a temporary trade-off between inflation and unemployment, although there isn't a permanent trade-off in the long term. Hence, he highlights that the temporary trade-off is not explained by the inflation itself, but by the non-expected inflation, which generally generates an increase in the inflation rate.

Despite this, there have been several modifications in the Phillips curve, since the hypothesis of the natural unemployment rate (Lucas, 1972a; Phelps, 1995) passing by the rational expectation theory (Muth, 1961; Lucas, 1972b; Sargent, 1973; Barro, 1976, 1977), among other relevant modifications, the trade-off between inflation and unemployment is still generally accepted.

However, a correlation between two variables does not mean causality and, in this sense, the relation of causality 
can result in three possible results: there is no causality, there is two way-causality, and there is a one-way causality. The empirical models on the Phillips curve implicitly assume that there is a one-way causality from the unemployment rate to the inflation rate.

Sasongko and Huruta (2018) show that the variation of unemployment rate causes the inflation rate based on Granger causality tests. Since the unemployment rate variable is not stationary, but the inflation rate is, the authors used the unemployment rate in the first difference. This procedure is usual because it is not possible to use variables $I(0)$ and $I(1)$ together. However, this adaptation is different from the original Phillips curve. This is just one example, but there are many in the literature. So what?

The point is that the Phillips curve relates the inflation rate to the unemployment rate instead of the inflation rate to variation in the unemployment rate. The unemployment rate variable is already measured as a proportion of unemployed people. Therefore, when one uses the first difference, the original Phillips curve is not being evaluated anymore, but rather the relationship between the inflation rate and the variation in the unemployment rate. Hence, this study is not the same, and the empirical results would not be the same as well. Such modifications can be accepted as an evolution of the Phillips curve, as well as the evaluation between the variation of the inflation rate and the unemployment rate that took place in the American economy from the 1970s onwards. These changes to the original Phillips Curve started to be called the modified Phillips curve or expectations-Augmented Phillips curve. In this context, McCallum (1982) contextualizes and analyzes some critical issues of macroeconomics based on rational expectations in the 1970s.

It is worth noting that Hooper et al. (2020) show as the US labor market has tightened beyond full employment with relatively little evidence of inflation pressure. Hence, the authors are increasingly inclined to declare the demise of the Phillips curve, since the flattening of its slope to zero. In other words, there is some empirical evidence that there isn't a trade-off between the unemployment rate and the inflation rate.

The first motivation of this paper is to evaluate if there are causal relations between the unemployment rate and the inflation rate, as the original Phillips curve, instead of the followings cases:

i) relation between variation of the inflation rate and unemployment rate.

ii) relation between the inflation rate and variation of unemployment rate.

iii) relation between the variation of the inflation rate and variation of the unemployment rate.

In this context, this paper aims to evaluate at first the causality between the unemployment rate and inflation rate for the US economy based on quarterly data from 1959:04 to 2019:04. In other words, this article is interested in analyzing the main assumption of the original Phillips curve, i.e., if there is a one-way causality in which the unemployment rate causes the inflation rate. Nonetheless, if this assumption is not confirmed based on Granger's causality tests, it could be interesting to evaluate new approaches theoretically or empirically between both variables. As this is the case, one can test the relation between the unemployment rate and the variability of inflation rate based on several empirical models if the Granger causality tests generate a one-way causality. Besides, one can also incorporate the monetary policy based on the variability of the real interest rate in the empirical models. As a result, one can test a new approach between the variance of the inflation rate and the unemployment rate. However, the contribution of this paper is evaluating if the variance of the inflation rate affects the unemployment rate and, besides, if there is a one-way causality from the variance of the inflation rate to the unemployment rate.

The questions that should arise, considering the previous paragraph, should refer to the reason for the use of the variability of inflation rates, as well as of the real interest rate. In this context, from the worker's point of view, given the rigidity of nominal wages, the greater the volatility of the inflation rate is, the greater the variability of real wages will be. In this way, one creates an environment of uncertainty and instability in the job market, which can contribute to the increase in unemployment. In the same vein, from the company's point of view, greater volatility in the real interest rate implies greater uncertainty and instability regarding the decision to invest on productive activities, which contributes to lower demand for workers. In other words, with the greatest uncertainty due to the volatility of the real interest rate, it becomes difficult for the entrepreneur to compare the return rate of his investment project with the real market interest rate. The firm tends to invest when the rate of return on its project is higher than the real interest rate, considering still that the real interest rate will be reasonably predictable and stable in the medium and long term.

\section{Method}

Table 1 shows the description of the database from the Federal Reserve Bank where the first part (Variable's description 1) displays the time series data and their respective codes and definitions. The second part (Variable's 
description 2) exhibits the transformed variables used in the estimations of the unemployment rate and unemployment cycle.

There are three dependent variables in percent. The first one is the unemployment rate. The others show the unemployment cycle; one of them is measured by the difference between the unemployment rate and the natural unemployment rate in long term, while the other is given by the difference between the unemployment rate and the natural unemployment rate in the short term.

The first explanatory variable is a dispersion measure based on the variance of Consumer Price Index rate, i.e., the variance of inflation rate, which is the main variable of interest. The second one is the control variable measured by the difference between the real GDP and the trend from Hodrick and Prescott Filter, which is a proxy for business cycle or output-gap.

Table 1. Database (Quarterly data from 1959:04 to 2019:04)

\begin{tabular}{lc}
\hline Variables code from FRED & Variable's description 1 \\
\hline LRHUTTTTUSQ156N & Harmonized Unemployment Rate: Total: All Persons for the United States, Percent \\
NROU & Natural Rate of Unemployment (Long-Term), Percent \\
NROUST & Natural Rate of Unemployment (Short-Term), Percent \\
GDPC1 & Real Gross Domestic Product, Billions of Chained 2012 Dollars \\
CPALTT01USQ657N & Consumer Price Index: Total All Items for the United States, Growth Rate Previous Period \\
BOGZ1FL072052006Q & Interest Rates and Price Indexes; Effective Federal Funds Rate (Percent), Level, Percent \\
\hline Variables & Variable's description 2 \\
\hline Unemployment Rate & Harmonized Unemployment Rate: Total: All Persons for the United States, Percent \\
Unemployment cycle LT ${ }^{(3)}$ & (Unemployment Rate) - (NROU) \\
Unemployment cycle ST ${ }^{(3)}$ & (Unemployment Rate) - (NROUST) \\
Business cycle ${ }^{(1)}$ & (GDPC1 - HP trend) \\
Inflation rate & CPALTT01USQ657N \\
Variance of Inflation Rate ${ }^{(2)}$ & Variance of CPALTT01USQ657N \\
Real Interest rate & (BOGZ1FL072052006Q) - (CPALTT01USQ657N) \\
Variance of real interest rate & $(2)$
\end{tabular}

Data source: Federal Reserve Bank of St. Louis.

Note. 1): HP_Trend $=$ Hodrick-Prescott Filter. 2): Variance $=\Sigma(\mathrm{Xi}-\mu)^{2} /(\mathrm{n}-1)$, where $\mu=$ mean and $\mathrm{n}=$ number of observations. 3$): \mathrm{LT}=$ Long Term and ST $=$ Short term.

Table 2. Descriptive statistics

\begin{tabular}{ccccccc}
\hline & $\begin{array}{c}\text { Unemployment } \\
\text { rate }\end{array}$ & $\begin{array}{c}\text { Unemployment } \\
\text { Cycle LT }\end{array}$ & $\begin{array}{c}\text { Unemployment } \\
\text { Cycle ST }\end{array}$ & $\begin{array}{c}\text { Business } \\
\text { cycle }\end{array}$ & $\begin{array}{c}\text { Variance of } \\
\text { inflation rate }\end{array}$ & $\begin{array}{c}\text { Variance of real } \\
\text { interest rate }\end{array}$ \\
\hline Mean & 5.957953 & 0.454973 & 0.407689 & $-1.46 \mathrm{E}-10$ & 0.002732 & 0.042883 \\
Median & 5.633333 & 0.172783 & 0.172783 & -6.404194 & 0.000784 & 0.015105 \\
Maximum & 11.16667 & 5.394181 & 5.053778 & 373.3346 & 0.058203 & 0.673616 \\
Minimum & 3.200000 & -2.626905 & -2.626905 & -419.3459 & $2.61 \mathrm{E}-08$ & $1.40 \mathrm{E}-06$ \\
Std. Dev. & 1.640114 & 1.584930 & 1.494764 & 128.8049 & 0.006164 & 0.079200 \\
\hline
\end{tabular}

Note. 241 observations.

Table 3. Correlation matrix

\begin{tabular}{lcccccc}
\hline & $\begin{array}{c}\text { Unemployment } \\
\text { rate }\end{array}$ & $\begin{array}{c}\text { Unemployment } \\
\text { cycle LT }\end{array}$ & $\begin{array}{c}\text { Unemployment } \\
\text { cycle ST }\end{array}$ & $\begin{array}{c}\text { Business } \\
\text { cycle }\end{array}$ & $\begin{array}{c}\text { Variance of } \\
\text { inflation rate }\end{array}$ & $\begin{array}{c}\text { Variance of real } \\
\text { interest rate }\end{array}$ \\
\hline Unemployment rate & 1 & 0.948 & 0.953 & -0.538 & 0.069 & 0.332 \\
Unemployment cycle LT & & 1 & 0.996 & -0.551 & 0.016 & 0.301 \\
Unemployment cycle ST & & & 1 & -0.560 & 0.017 & 0.304 \\
Business cycle & & & & 1 & 0.083 & -0.060 \\
Variance of inflation rate & & & & & 1 & 0.249 \\
Variance of real interest rate & & & & & & 1 \\
\hline
\end{tabular}

Table 2 exhibits the descriptive statistics of the empirical models' variables. It is worth highlighting the statistics from the three dependent variables. Although the mean of unemployment rate is about $6 \%$, the mean of both 
unemployment cycles variables ranges between 0.40 and 0.46 , because both unemployment cycle variables deduce from the unemployment rate the variables related to unemployment natural of the long term as well as of the short term.

The correlation matrix presented in Table 3, shows that there are no high correlations between the three dependent variables and the explanatory variables. In this way, the problem of multicollinearity is avoided. In addition, each of the three dependent variables shows a positive correlation with the variance of inflation rate. On the other hand, such dependent variables show a negative correlation with the variable business cycle. However, correlation is not causality. In this sense, it is relevant investigating causal relations between the inflation rate and unemployment rate.

Based on Granger (1969), one can test the causality between the dependent variables and the explanatory variables. Tables 1A, 1B and 1C show the Granger causality tests between the dependent variables and the inflation rate. The empirical results display that there are two way-causality relations between the unemployment rate and inflation rate, as well as between the variables of unemployment cycle (long term and short term) and inflation rate. These results are not consistent with the main presuppose of the Phillips curve, i.e., that there is a one-way causality from the unemployment rate to the inflation rate.

However, the Granger causality tests show that the variance of inflation rate causes unemployment rate, as well as causing unemployment cycle of long term and unemployment cycle of short term, as shown in the tables $2 \mathrm{~A}$, 2B and 2C. Moreover, the business cycle also causes unemployment rate, and in this same vein, causes unemployment cycle of long term and short term, as shown in the tables 3A, 3B and 3C. Besides, Structural VAR (SVAR) analysis is used in order to display impulse response functions.

Taking into account these first considerations, one can explicit the empirical equations as follows:

$$
\begin{gathered}
(\text { Business cycle })_{t}=\alpha o+\alpha_{1}(\text { Business cycle })_{t-1}+\alpha 2(\text { variance of real interest rate }) t+Z_{t} \\
U_{t}=\beta_{0+} \beta_{1} U_{t-1}+\beta_{2} U_{t-2}+\ldots+\beta_{n} U_{t-n}+\delta_{0}(\text { Business cycle })_{t}+\delta_{I}(\text { Variance of inflation rate }) t+\varepsilon_{t}
\end{gathered}
$$

Regarding equation 1 , the business cycle responds to variance of real interest rate, where parameter $\alpha o$ is the coefficient of the constant term; $\alpha_{2}$ is the lag from the dependent variable, and $Z_{t}$ is the error term. This equation is a simplified version of the IS curve.

Based on equation 2, the dependent variable $U t$ can be unemployment rate, unemployment cycle of long run or unemployment cycle of short run; $t$ is the time from $l$ to $n: \beta_{0}$ is the coefficient of the constant term; $\beta_{1}, \quad \beta_{2}, \ldots$ $\beta_{n}$ are the coefficient lags from the dependent variables, and $\varepsilon_{t}$ is the error term. It is expected that $\delta_{0}<0$, i.e., higher demand contributes to reducing the unemployment rate. Besides, if one expects a trade-off between the unemployment rate and the variance of inflation rate, so that $\delta_{1}<0$. Nonetheless, one should keep in mind that this new approach is not a new version of the Phillips curve, but it can show a new connection between both variables. In this context, based on the hypothesis inspired by Hayek (2011), in which the persistent increment of the inflation rate, due to monetary expansion, contributes to the increasing unemployment rate, one can expect that the coefficient from the variance of the inflation rate is positive, so that $\delta_{1}>0$.

Hayek (1979) argues that current unemployment is, in the final analysis, a direct and inevitable consequence of full employment policies, although in the short term it generates additional jobs. The policymakers' goal of keeping the economy in full employment, through expansionary economic policies, ends up resulting in misallocation of labor and, consequently, in more unemployment.

The strategy of the empirical approach begins with an empirical model based on ordinary least squares (OLS). After that, one tests the robustness of the empirical results based on other methods. In this context, one uses the robust least squares (RLS) method that refers to a variety of regression methods, which are robust, or less sensitive to outliers. There are some methods for RLS to determine a regression model: M-estimation (Huber, 1973), S-estimation (Rousseeuw \& Yohai, 1984), and MM-estimation (Yohai, 1987).

Moreira et al. (2016) also estimate a system of two regressions via GMM to avoid endogeneity problems using instrumental variables (IV). In this sense, the IV must be good in order to be relevant and valid. The authors use the test of over-identifying Sargan-Hansen also known as J-statistic. Besides, the Stock-Yogo test (2005) evaluates the null hypothesis, which the instruments are weak, based on the Cragg-Donald test. In this context, see Moreira (2001), Stock and Yogo (2004), or Stock, Wright, and Yogo (2002). Moreover, they use the procedure of Newey and West (1987a, 1987b) for all estimated models to minimize problems of unknown heteroskedasticity, as well as serial correlation of the residuals. Hence, in order to test the empirical results robustness in this article, one follows Moreira et al. (2016), who show in more detail the methodological aspects. 


\section{Results}

Table 4 shows that all the variables are statistically significant at 5\% level, and hence all of them are stationary series.

Table 4. Unit root tests (H0: time series has unit root)

\begin{tabular}{lcccccc}
\hline & \multicolumn{3}{c}{ Augmented Dickey-Fuller test statistic (ADF) } & \multicolumn{3}{c}{ Phillips-Perron test statistic (P.P.) } \\
\hline Variables & Critical value: 5\% level & t-Statistic & p-value & Critical value: 5\% level & Adj. t-Stat & p-value \\
\hline Inflation rate & -2.87349 & -3.28107 & 0.0169 & -2.873390 & -7.51315 & $<0.001$ \\
Variance of inflation rate & -2.87349 & -5.04323 & $<0.001$ & -2.873390 & -10.1967 & $<0.001$ \\
Unemployment Rate & -2.87380 & -3.69779 & 0.0047 & -2.873390 & -3.18863 & 0.0219 \\
Unemployment cycle Long Term & -2.87380 & -3.77077 & 0.0037 & -2.873390 & -3.35197 & 0.0137 \\
Unemployment cycle Shor Term & -2.87380 & -3.79293 & 0.0034 & -2.873390 & -3.50197 & 0.0087 \\
Business cycle & -2.87349 & -5.75892 & $<0.001$ & -2.873390 & -4.88722 & $<0.001$ \\
Variance of real interest rate & -2.87349 & -3.19507 & 0.0215 & -2.873390 & -7.68247 & $<0.001$ \\
\hline
\end{tabular}

Note. Include Constant.

\subsection{Granger Causality Tests and Structural VAR}

This subsection shows granger causality tests and structural VAR (SVAR) analysis. Good descriptions of structural VAR can be found in Hamilton (1994) and Stock and Watson (2001), for instance. The SVAR allows deriving the impulse response functions considering a period of three years, i.e., twelve quarters.

Based on the Phillips curve, one expects that unemployment rate causes inflation rate. However, the Granger causality tests display a two-way causality relation between them according to Table 1A. Figure 1 shows impulse response functions between both variables with 11 lags. Tables $1 \mathrm{~B}$ and 1C also show a two-way causality between the inflation rate and unemployment cycle in the long term, as well as between inflation rate and unemployment cycle in the short term. Figures $1 \mathrm{~B}$ and $1 \mathrm{C}$ also show impulse response functions with 11 lags.

Table 1A. Granger causality tests (inflation rate \& unemployment rate)

\begin{tabular}{|c|c|c|c|}
\hline Null Hypothesis: & Obs. & F-Statistic & Prob. \\
\hline Inflation rate does not granger cause unemployment rate & 235 & 3.79960 & 0.0013 \\
\hline Unemployment rate does not granger cause inflation rate & & 2.69904 & 0.0150 \\
\hline \multicolumn{4}{|l|}{6 lags order selected by the $\mathrm{SC}$ criterion } \\
\hline Null hypothesis: & obs. & f-statistic & prob. \\
\hline Inflation rate does not granger cause unemployment rate & 234 & 3.41382 & 0.0017 \\
\hline Unemployment rate does not granger cause inflation rate & & 3.74353 & 0.0007 \\
\hline \multicolumn{4}{|l|}{7 lags order selected by the HQ criterion } \\
\hline Null hypothesis: & obs. & f-statistic & prob. \\
\hline Inflation rate does not granger cause unemployment rate & 230 & 2.14858 & 0.0185 \\
\hline Unemployment rate does not granger cause inflation rate & & 3.15021 & 0.0006 \\
\hline 11 lags order selected by the LR, FPE and AIC criterions & & & \\
\hline
\end{tabular}

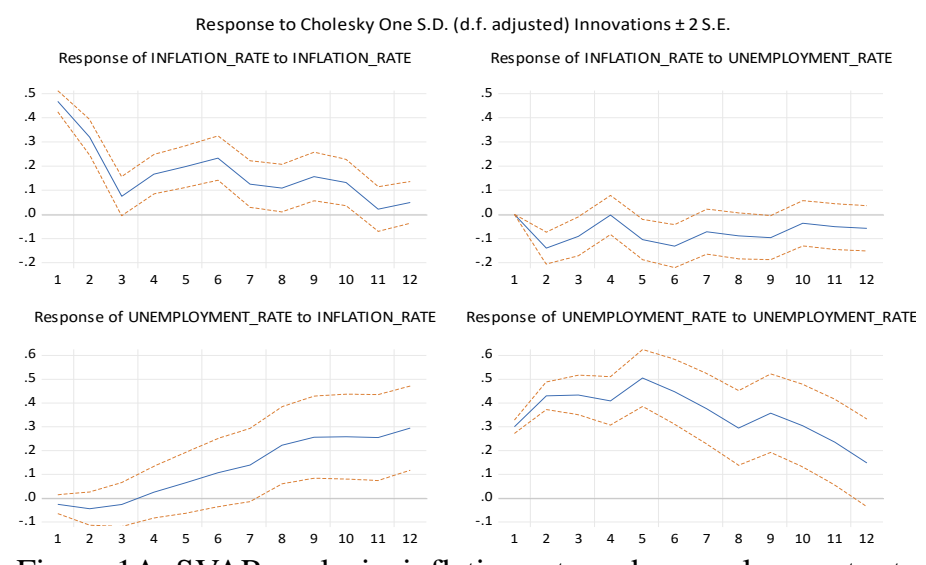

Figure 1A. SVAR analysis: inflation rate and unemployment rate 
Table 1B. Granger causality tests (inflation rate \& unemployment cycle long term)

\begin{tabular}{lccc}
\hline Null Hypothesis: & Obs. & F-Statistic & Prob. \\
\hline Inflation Rate does not Granger Cause Unemployment Cycle LT & 235 & 2.97206 & 0.0082 \\
Unemployment Cycle LT does not Granger Cause Inflation Rate & & 3.14263 & 0.0056 \\
6 lags order selected by the SC criterion & & & \\
\hline Null Hypothesis: & Obs. & F-Statistic & Prob. \\
Inflation Rate does not Granger Cause Unemployment Cycle LT & 234 & 2.63072 & 0.0125 \\
Unemployment Cycle LT does not Granger Cause Inflation Rate & & 4.14180 & 0.0003 \\
7 lags order selected by the HQ criterion & & & \\
\hline Null Hypothesis: & Obs. & F-Statistic & Prob. \\
Inflation Rate does not Granger Cause Unemployment Cycle LT & 230 & 1.74107 & 0.0665 \\
Unemployment Cycle LT does not Granger Cause Inflation Rate & & 3.40896 & 0.0002 \\
11 lags order selected by the LR, FPE and AIC criterions & & &
\end{tabular}

Note. 1) Criterions - LR: sequential modified LR test statistic (each test at 5\% level), FPE: Final prediction error, AIC: Akaike information criterion, SC: Schwarz information criterion and HQ: Hannan-Quinn information criterion.

2) Quarterly data from 1959:04 to 2019:04.

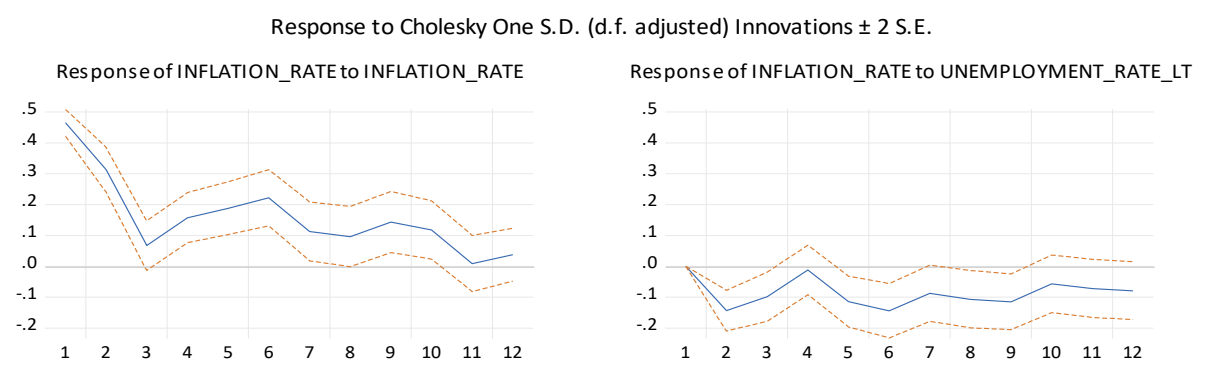

Response of UNEMPLOYMENT_RATE_LT to INFLATION_RATE Response of UNEMPLOYMENT_RATE_LT to UNEMPLOYMENT_RATE_LT
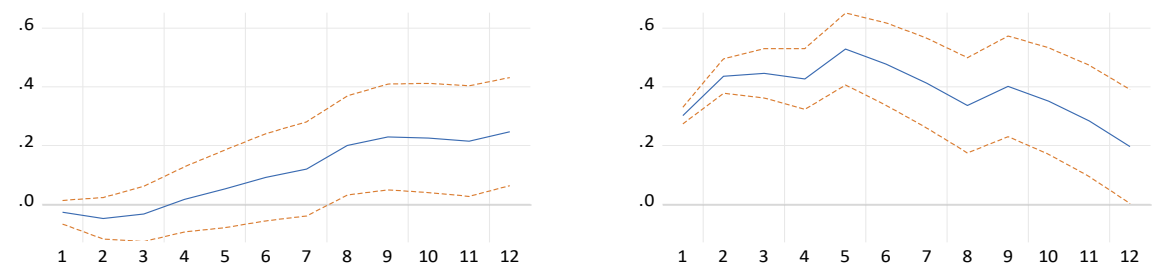

Figure 1B. SVAR analysis: inflation rate and unemployment cycle LT

Table 1C. Granger causality tests (inflation rate \&unemployment cycle short term)

\begin{tabular}{|c|c|c|c|}
\hline Null Hypothesis: & Obs. & F-Statistic & Prob. \\
\hline Inflation Rate does not Granger Cause Unemployment Cycle ST & 235 & 3.21121 & 0.0048 \\
\hline Unemployment Cycle ST does not Granger Cause Inflation Rate & & 3.19020 & 0.0050 \\
\hline \multicolumn{4}{|l|}{6 lags order selected by the SC criterion } \\
\hline Null Hypothesis: & Obs. & F-Statistic & Prob. \\
\hline Inflation Rate does not Granger Cause Unemployment Cycle ST & 234 & 2.84770 & 0.0073 \\
\hline Unemployment Cycle ST does not Granger Cause Inflation Rate & & 4.32465 & 0.0002 \\
\hline \multicolumn{4}{|l|}{7 lags order selected by the HQ criterion } \\
\hline Null Hypothesis: & Obs. & F-Statistic & Prob. \\
\hline Inflation Rate does not Granger Cause Unemployment Cycle ST & 230 & 1.75074 & 0.0646 \\
\hline Unemployment Cycle ST does not Granger Cause Inflation Rate & & 3.53325 & 0.0001 \\
\hline
\end{tabular}

11 lags order selected by the LR, FPE and AIC criterions

Note. 1) Criterions - LR: sequential modified LR test statistic (each test at 5\% level), FPE: Final prediction error, AIC: Akaike information criterion, SC: Schwarz information criterion and HQ: Hannan-Quinn information criterion.

2) Quarterly data from 1959:04 to 2019:04. 


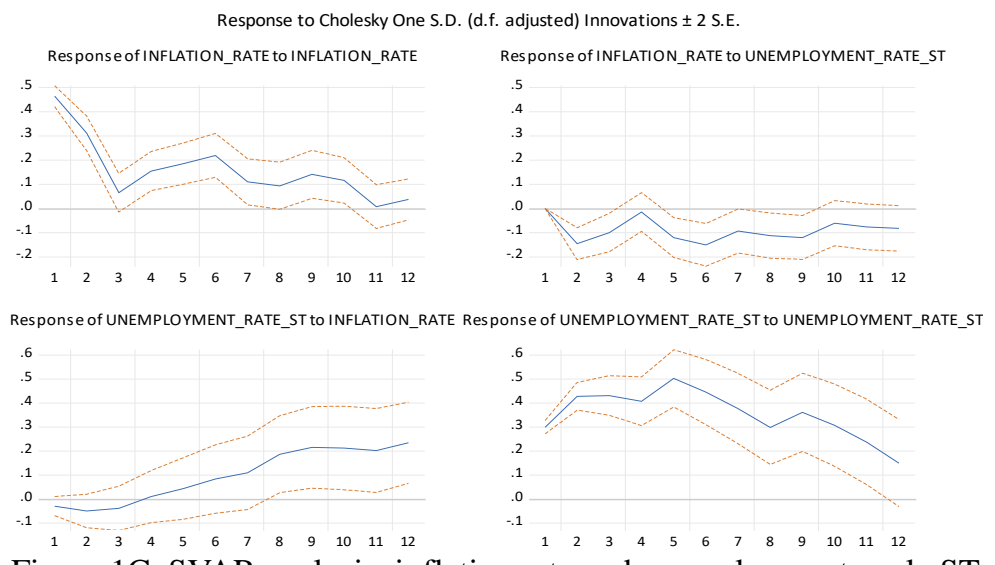

Figure 1C. SVAR analysis: inflation rate and unemployment cycle ST

These empirical results of two-way causality motivated a new investigation on the causality relation between both variables. In this context, one opts for the relation between the unemployment rate and a dispersion measure for the inflation rate in order to get a causality relation in just one direction. In this sense, based on Tables 2A, $2 \mathrm{~B}$, and $2 \mathrm{C}$, the Granger causality tests do not accept the null hypothesis as follows:

i) Variance of the inflation rate does not Granger cause unemployment rate; ii) variance of the inflation rate does not Granger cause unemployment rate in the long term and iii) variance of the inflation rate does not Granger cause unemployment rate in the short term. Therefore, the variance of inflation rate shows a one-way causality from variance of inflation rate to three dependent variables: unemployment rate, unemployment cycle in the long term, and unemployment cycle in the short term. Figures 2A, 2B and 2C also display impulse response functions with 6 lags.

Table 2A. Granger causality tests (variance of inflation rate \& unemployment rate)

\begin{tabular}{|c|c|c|c|}
\hline Null Hypothesis: & Obs. & F-Statistic & Prob. \\
\hline Variance of inflation rate does not Granger Cause Unemployment rate & 235 & 9.10246 & 7.E-09 \\
\hline $\begin{array}{l}\text { Unemployment rate does not Granger Cause Variance of inflation rate } \\
6 \text { lags order selected by the SC and HQ criterions }\end{array}$ & & 1.14042 & 0.3398 \\
\hline Null Hypothesis: & Obs. & F-Statistic & Prob. \\
\hline Variance of inflation rate does not Granger Cause Unemployment rate & 231 & 7.48673 & 4.E-10 \\
\hline $\begin{array}{l}\text { Unemployment rate does not Granger Cause Variance of inflation rate } \\
10 \text { lags order selected by the FPE and AIC criterion }\end{array}$ & & 0.79794 & 0.6308 \\
\hline Null Hypothesis: & Obs. & F-Statistic & Prob. \\
\hline Variance of inflation rate does not Granger Cause Unemployment rate & 228 & 5.90604 & 3.E-09 \\
\hline $\begin{array}{l}\text { Unemployment rate does not Granger Cause Variance of inflation rate } \\
13 \text { lags order selected by the LR criterion }\end{array}$ & & 0.74540 & 0.7166 \\
\hline
\end{tabular}

Note. 1) Criterions - LR: sequential modified LR test statistic (each test at 5\% level), FPE: Final prediction error, AIC: Akaike information criterion, SC: Schwarz information criterion and HQ: Hannan-Quinn information criterion. 2) Quarterly data from 1959:04 to 2019:04.

Response to Cholesky One S.D. (d.f. adjusted) Innovations \pm 2 S.E.

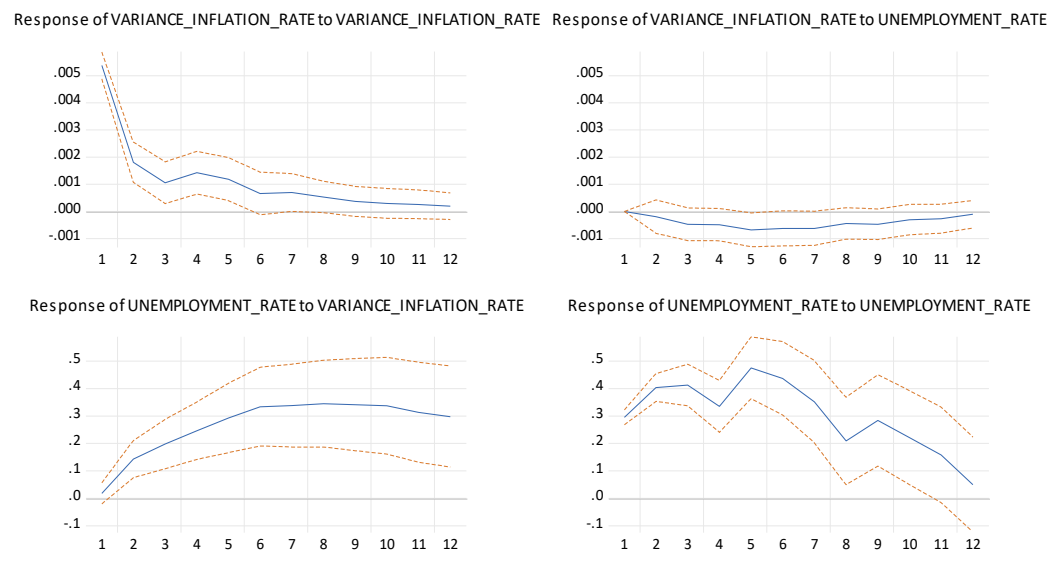

Figure 2A. SVAR analysis: Variance of inflation rate and unemployment rate 
Table 2B. Granger causality tests (variance of inflation rate \& unemployment cycle LT)

\begin{tabular}{|c|c|c|c|}
\hline Null Hypothesis: & Obs. & F-Statistic & Prob. \\
\hline Variance of inflation rate does not Granger Cause Unemployment cycle LT & 235 & 8.70968 & 2.E-08 \\
\hline Unemployment cycle LT does not Granger Cause Variance of inflation rate & & 1.30349 & 0.2566 \\
\hline \multicolumn{4}{|l|}{6 lags order selected by the SC and HQ criterions } \\
\hline Null Hypothesis: & Obs. & F-Statistic & Prob. \\
\hline Variance of inflation rate does not Granger Cause Unemployment cycle LT & 231 & 6.96740 & 2.E-09 \\
\hline Unemployment cycle LT does not Granger Cause Variance of inflation rate & & 0.89269 & 0.5409 \\
\hline \multicolumn{4}{|l|}{10 lags order selected by the FPE and AIC criterions } \\
\hline Null Hypothesis: & Obs. & F-Statistic & Prob. \\
\hline Variance of inflation rate does not Granger Cause Unemployment cycle LT & 228 & 5.49339 & 2.E-08 \\
\hline Unemployment cycle LT does not Granger Cause Variance of inflation rate & & 0.81803 & 0.6407 \\
\hline
\end{tabular}

13 lags order selected by the LR criterion

Note. 1) Criterions - LR: sequential modified LR test statistic (each test at 5\% level), FPE: Final prediction error, AIC: Akaike information criterion, SC: Schwarz information criterion and HQ: Hannan-Quinn information criterion.

2) Quarterly data from 1959:04 to 2019:04.

Response to Cholesky One S.D. (d.f. adjusted) Innovations \pm 2 S.E.

Response of VARIANCE_INFLATION_RATE to VARIANCE_INFLATION_RATE Response of VARIANCE_INFLATION_RATE to UNEMPLOYMENT_RATE_LT
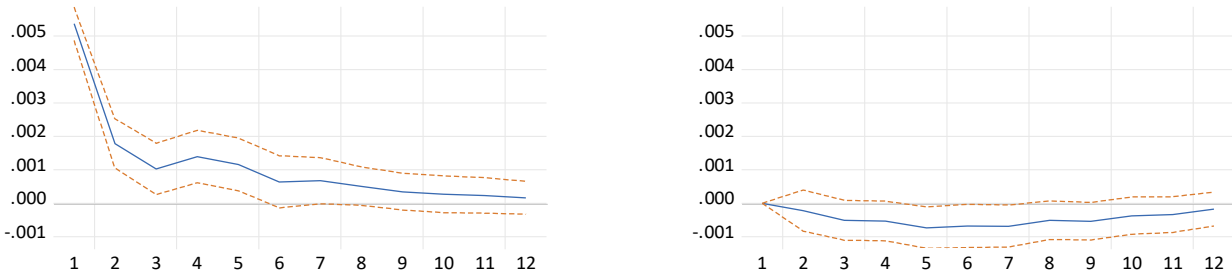

Response of UNEMPLOYMENT_RATE_LT to VARIANCE_INFLATION_RATE

Response of UNEMPLOYMENT_RATE_LT to UNEMPLOYMENT_RATE_LT
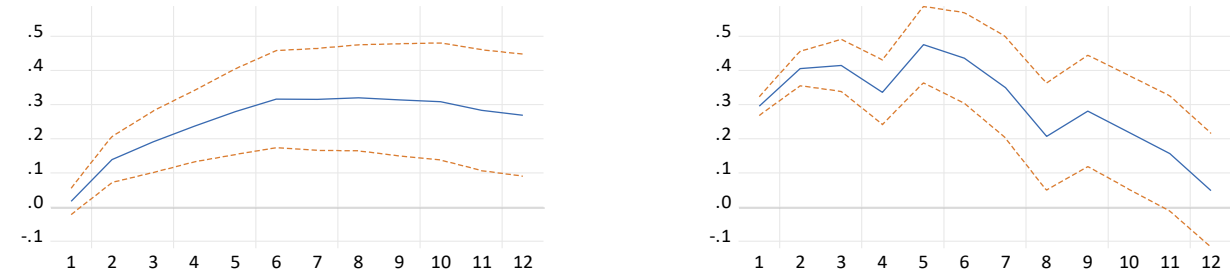

Figure 2B. SVAR analysis: variance of inflation rate and unemployment cycle LT

Table 2C. Granger Causality Tests (Variance of inflation rate \& Unemployment cycle ST)

\begin{tabular}{lccc}
\hline Null Hypothesis: & Obs. & F-Statistic & Prob. \\
\hline Variance of inflation rate does not Granger Cause Unemployment cycle ST & 235 & 8.75446 & 1. E-08 \\
Unemployment cycle ST does not Granger Cause Variance of inflation rate & & 1.29588 & 0.2601 \\
6 lags order selected by the SC and HQ criterions & & & \\
\hline Null Hypothesis: & Obs. & F-Statistic & Prob. \\
Variance of inflation rate does not Granger Cause Unemployment cycle ST & 231 & 6.96093 & $2 . E-09$ \\
Unemployment cycle ST does not Granger Cause Variance of inflation rate & & 0.88647 & 0.5467 \\
10 lags order selected by the FPE and AIC criterions & & & \\
\hline Null Hypothesis: & Obs. & F-Statistic & Prob. \\
Variance of inflation rate does not Granger Cause Unemployment cycle ST & 228 & 5.46497 & 2. E-08 \\
Unemployment cycle ST does not Granger Cause Variance of inflation rate & & 0.82392 & 0.6344 \\
13 lags order selected by the LR criterion & & & \\
\hline
\end{tabular}

Note. 1) Criterions - LR: sequential modified LR test statistic (each test at 5\% level), FPE: Final prediction error, AIC: Akaike information criterion, SC: Schwarz information criterion and HQ: Hannan-Quinn information criterion.

2) Quarterly data from 1959:04 to 2019:04. 
Response to Cholesky One S.D. (d.f. adjusted) Innovations \pm 2 S.E.

Response of INFLATION_RATE to INFLATION_RATE
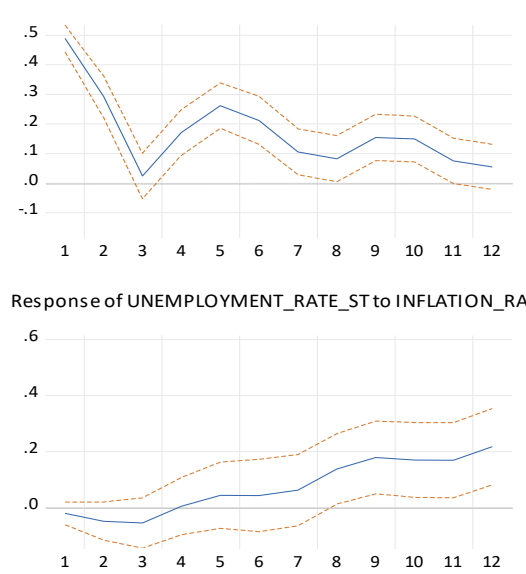

Response of INFLATION_RATE to UNEMPLOYMENT_RATE_ST

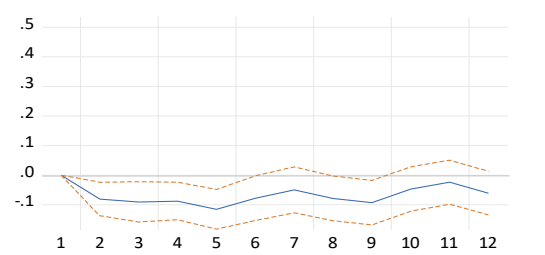

Figure 2C. SVAR analysis: variance of inflation rate and Unemployment cycle ST

Finally, Tables 3A, 3B, and 3C exhibit the Granger causality tests between the business cycle and the three dependent variables. The empirical results reveal a one-way causality from business cycle to all the dependent variables. Figures 3A, 3B and 3C also reveal impulse response functions with 13 lags.

Table 3A. Granger causality tests (business cycle \& unemployment rate)

\begin{tabular}{|c|c|c|c|}
\hline Null Hypothesis: & Obs. & F-Statistic & Prob. \\
\hline Business cycle does not Granger Cause Unemployment rate & 235 & 6.98628 & 8.E-07 \\
\hline Unemployment rate does not Granger Cause Business cycle & & 1.14042 & 0.3398 \\
\hline \multicolumn{4}{|l|}{6 lags order selected by the SC criterions } \\
\hline Null Hypothesis: & Obs. & F-Statistic & Prob. \\
\hline Business cycle does not Granger Cause Unemployment rate & 232 & 7.85300 & 5.E-10 \\
\hline Unemployment rate does not Granger Cause Business cycle & & 1.54203 & 0.1348 \\
\hline \multicolumn{4}{|l|}{09 lags order selected by the HQ criterion } \\
\hline Null Hypothesis: & Obs. & F-Statistic & Prob. \\
\hline Business cycle does not Granger Cause Unemployment rate & 228 & 6.17024 & 1.E-09 \\
\hline Unemployment rate does not Granger Cause Business cycle & & 1.00158 & 0.4511 \\
\hline 13 lags order selected by the LR, FPE, AIC criterions & & & \\
\hline
\end{tabular}

Note. 1) Criterions - LR: sequential modified LR test statistic (each test at 5\% level), FPE: Final prediction error, AIC: Akaike information criterion, SC: Schwarz information criterion and HQ: Hannan-Quinn information criterion.

2) Quarterly data from 1959:04 to 2019:04.

Response to Cholesky One S.D. (d.f. adjusted) Innovations \pm 2 S.E.

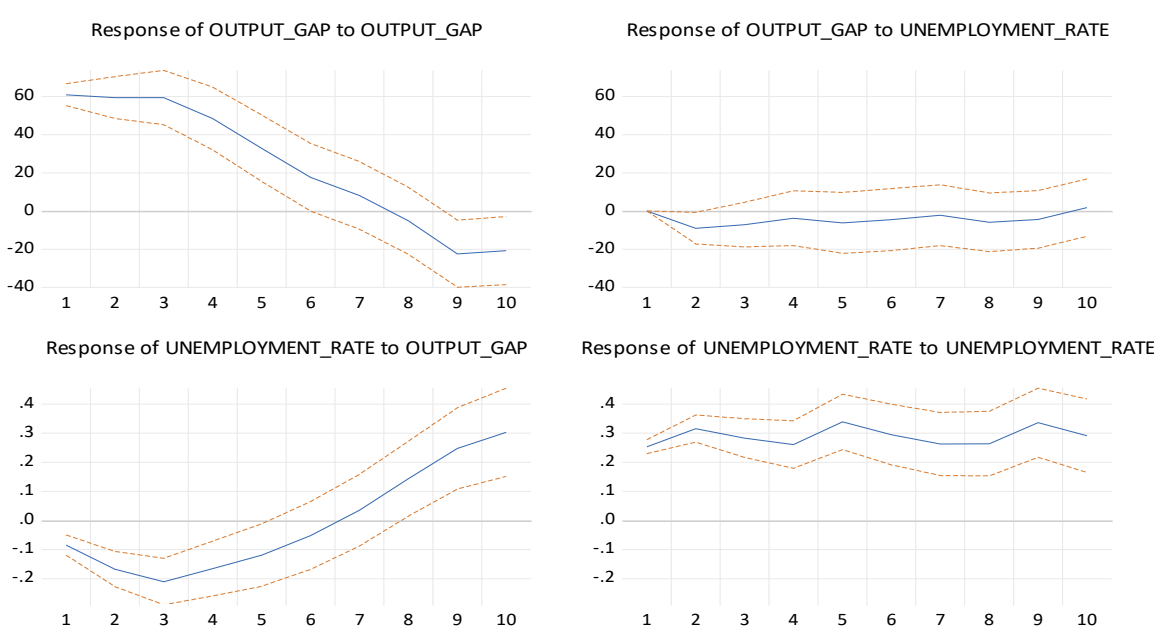

Figure 3A. SVAR analysis: Business cycle and Unemployment rate 
Table 3B. Granger causality tests (business cycle unemployment cycle LT)

\begin{tabular}{|c|c|c|c|}
\hline Null Hypothesis: & Obs. & F-Statistic & Prob. \\
\hline Business cycle does not Granger Cause Unemployment cycle LT & 235 & 7.02598 & 7.E-07 \\
\hline Unemployment cycle LT does not Granger Cause Business cycle & & 1.17675 & 0.3197 \\
\hline \multicolumn{4}{|l|}{6 lags order selected by the SC criterions } \\
\hline Null Hypothesis: & Obs. & F-Statistic & Prob. \\
\hline Business cycle does not Granger Cause Unemployment cycle LT & 232 & 7.85264 & 5.E-10 \\
\hline Unemployment cycle LT does not Granger Cause Business cycle & & 1.61233 & 0.1132 \\
\hline \multicolumn{4}{|l|}{09 lags order selected by the HQ criterion } \\
\hline Null Hypothesis: & Obs. & F-Statistic & Prob. \\
\hline Business cycle does not Granger Cause Unemployment cycle LT & 228 & 5.49339 & 2.E-08 \\
\hline Unemployment cycle LT does not Granger Cause Business cycle & & 0.81803 & 0.6407 \\
\hline
\end{tabular}

Note. 1) Criterions - LR: sequential modified LR test statistic (each test at 5\% level), FPE: Final prediction error, AIC: Akaike information criterion, SC: Schwarz information criterion and HQ: Hannan-Quinn information criterion.

2) Quarterly data from 1959:04 to 2019:04.

Response to Cholesky One S.D. (d.f. adjusted) Innovations \pm 2 S.E.

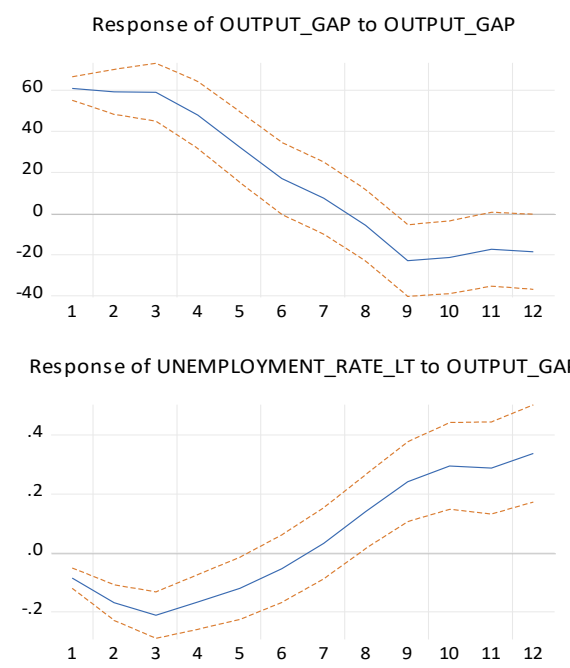
Response of OUTPUT_GAP to UNEMPLOYMENT_RATE_LT

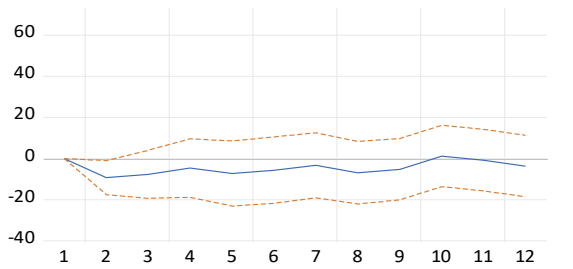

Figure 3B. SVAR analysis: business cycle and unemployment cycle LT

Table 3C. Granger causality tests (business cycle \& unemployment cycle ST)

\begin{tabular}{lccc}
\hline Null Hypothesis: & Obs. & F-Statistic & Prob. \\
\hline Business cycle does not Granger Cause Unemployment cycle ST & 235 & 7.15638 & 5. E-07 \\
Unemployment cycle ST does not Granger Cause Business cycle & & 1.14693 & 0.3361 \\
6 lags order selected by the SC criterions & & & \\
\hline Null Hypothesis: & Obs. & F-Statistic & Prob. \\
Business cycle does not Granger Cause Unemployment cycle ST & 232 & 7.76185 & $7 . E-10$ \\
Unemployment cycle ST does not Granger Cause Business cycle & & 1.62203 & 0.1104 \\
09 lags order selected by the HQ criterion & & & \\
\hline Null Hypothesis: & Obs. & F-Statistic & Prob. \\
Business cycle does not Granger Cause Unemployment cycle ST & 228 & 5.92524 & $3 . E-09$ \\
Unemployment cycle ST does not Granger Cause Business cycle & & 1.06291 & 0.3935
\end{tabular}

13 lags order selected by the LR, FPE, AIC criterions

Note. 1) Criterions - LR: sequential modified LR test statistic (each test at 5\% level), FPE: Final prediction error, AIC: Akaike information criterion, SC: Schwarz information criterion and HQ: Hannan-Quinn information criterion.

2) Quarterly data from 1959:04 to 2019:04. 


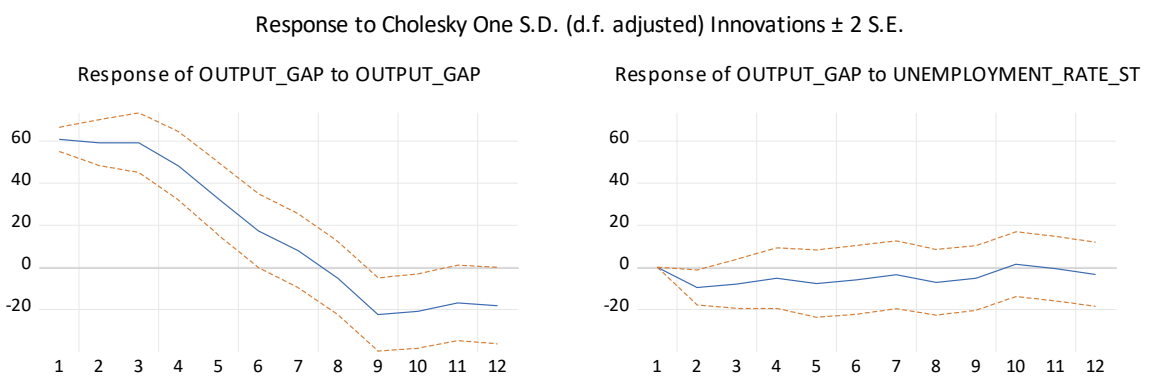

Response of UNEMPLOYMENT_RATE_ST to OUTPUT_GAP Response of UNEMPLOYMENT_RATE_ST to UNEMPLOYMENT_RATE_ST
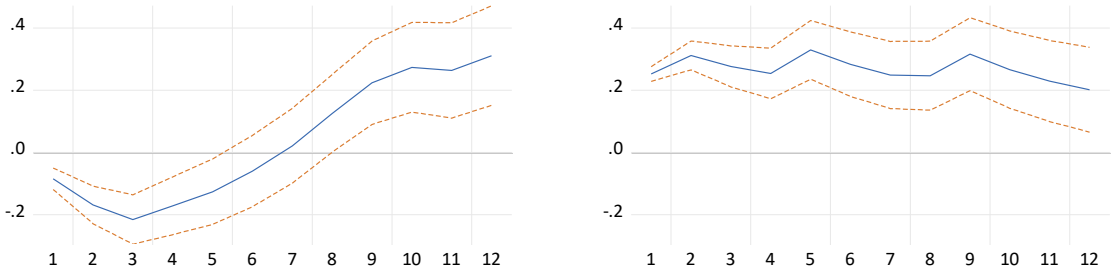

Figure 3C. SVAR analysis: business cycle and unemployment cycle ST

Hence, in next section, one can test equation (2) that shows an econometric specification different from the Phillips curve, so that the variables of unemployment are explained by the variance of inflation rate and by the control variable business cycle. In other words, it is not the unemployment rate that explains the inflation rate according to the Philipps Curve, but here it is the variance of the inflation rate that explains the unemployment rate, taking into account the Granger causality tests.

\subsection{Ordinary Last Squares Models}

Based on OLS models, Table 5 displays the empirical results of the three models where the second, third and fourth columns show the dependent variables: unemployment rate, unemployment cycles in the long run and short run respectively. There are six lags from each one of the dependent variables in which the estimated coefficients are statistically significant at $1 \%$ level. The estimated coefficients in the seventh lag are not statistically significant for the three estimated models.

The explanatory variable business cycle and the main variable of interest, variance of inflation rate, are also statistically significant at $1 \%$ level. While the estimated coefficient regarding business cycle is negative, showing that an excess of demand reduces the unemployment rate, as well as unemployment cycles in the long run and short run; the variance of inflation rate has a direct and positive effect on the three dependent variables, i.e., the variance of inflation rate increases the unemployment rate and the unemployment cycle variables.

Table 5. Method: ordinary least squares (quarterly data from 1959:04 to 2019:04)

\begin{tabular}{|c|c|c|c|}
\hline Dependent variable & Unemployment rate & Unemployment cycle_LT & Unemployment cycle_ST \\
\hline & $\begin{array}{l}\text { Coefficient } \\
\text { (Std.Error) }\end{array}$ & $\begin{array}{l}\text { Coefficient } \\
\text { (Std.Error) }\end{array}$ & $\begin{array}{l}\text { Coefficient } \\
\text { (Std.Error) }\end{array}$ \\
\hline Constant & $\begin{array}{c}0.315647 * * * \\
(0.090460)\end{array}$ & $\begin{array}{l}-0.013711 \\
(0.023036)\end{array}$ & $\begin{array}{l}-0.013063 \\
(0.022806)\end{array}$ \\
\hline Unemployment rate $(-1)$ & $\begin{array}{c}1.306414 * * * \\
(0.056840)\end{array}$ & $\begin{array}{c}1.303640 * * * \\
(0.056868)\end{array}$ & $\begin{array}{c}1.289447 \text { *** } \\
(0.057079)\end{array}$ \\
\hline Unemployment rate $(-2)$ & $\begin{array}{c}-0.440991 * * * \\
(0.064418)\end{array}$ & $\begin{array}{c}-0.444773 * * * \\
(0.064217)\end{array}$ & $\begin{array}{c}-0.442155^{* * * *} \\
(0.064015)\end{array}$ \\
\hline Unemployment rate $(-3)$ & $\begin{array}{c}-0.132837 * * * \\
(0.044278)\end{array}$ & $\begin{array}{c}-0.132263^{* * *} \\
(0.044182)\end{array}$ & $\begin{array}{c}-0.132575 * * * \\
(0.043941)\end{array}$ \\
\hline Unemployment rate $(-4)$ & $\begin{array}{c}0.875768 * * * \\
(0.044577)\end{array}$ & $\begin{array}{c}0.874263^{* * * *} \\
(0.044510)\end{array}$ & $\begin{array}{c}0.870785^{* * * *} \\
(0.044288)\end{array}$ \\
\hline Unemployment rate $(-5)$ & $\begin{array}{c}-1.156331 * * * \\
(0.065437)\end{array}$ & $\begin{array}{c}-1.155024 * * * \\
(0.065328)\end{array}$ & $\begin{array}{c}-1.143819 * * * \\
(0.065205)\end{array}$ \\
\hline
\end{tabular}




\begin{tabular}{|c|c|c|c|}
\hline Unemployment rate (-6) & $\begin{array}{c}0.486954 * * * \\
(0.051731)\end{array}$ & $\begin{array}{c}0.490998 * * * \\
(0.051561)\end{array}$ & $\begin{array}{c}0.489203 * * * \\
(0.051610)\end{array}$ \\
\hline Business cycle & $\begin{array}{c}-0.000829 * * * \\
(0.000204)\end{array}$ & $\begin{array}{c}-0.000841^{* * *} \\
(0.000204)\end{array}$ & $\begin{array}{c}-0.000865^{* * *} \\
(0.000203)\end{array}$ \\
\hline \multirow[t]{2}{*}{ Variance of inflation rate } & $\begin{array}{c}1.424647 * * * \\
(0.3313021) \\
\end{array}$ & $\begin{array}{c}1.329957 * * * \\
(0.3293649) \\
\end{array}$ & $\begin{array}{c}1.277388 * * * \\
(0.3270818) \\
\end{array}$ \\
\hline & & Statistics & \\
\hline Adjusted R-squared & 0.965464 & 0.963155 & 0.959058 \\
\hline Durbin-Watson stat & 1.999780 & 1.989436 & 1.997370 \\
\hline F-statistic & 818.6868 & 765.6200 & 686.1724 \\
\hline Prob(F-statistic) & $<0.00001$ & $<0.00001$ & $<0.00001$ \\
\hline Heteroscedasticity Test & 0.6384 & 0.7658 & 0.7037 \\
\hline LM test at up to 2 lags & 0.9991 & 0.9715 & 0.9902 \\
\hline
\end{tabular}

\subsection{Robustness Tests}

Tables 5A, 5B and 5C present the same empirical models from Table 5 based on robust least squares methods. The empirical results show similarity with the results exhibited in Table 5. However, in order to avoid possible problems of endogeneity it is still necessary to test the empirical models via GMM with IV.

Table 5A. Dependent variable - unemployment rate (1959:04 - 2019:04)

\begin{tabular}{|c|c|c|c|c|}
\hline Variables & $\begin{array}{c}\text { MODEL } 1 \text { - OLS: HAC } \\
\text { standard errors \& } \\
\text { covariance } \\
\text { Coefficient (Std.Error) }\end{array}$ & $\begin{array}{l}\text { MODEL 2- Robust Least } \\
\text { Squares: (M-estimation) } \\
\text { Coefficient (Std.Error) }\end{array}$ & $\begin{array}{c}\text { MODEL 3 - Robust } \\
\text { Least Squares: } \\
\text { (S-estimation) } \\
\text { Coefficient (Std.Error) } \\
\end{array}$ & $\begin{array}{c}\text { MODEL } 4 \text { - Robust } \\
\text { Least Squares: } \\
\text { (MM-estimation) } \\
\text { Coefficient (Std.Error) } \\
\end{array}$ \\
\hline Constant & $\begin{array}{c}0.315647 * * * \\
(0.088492)\end{array}$ & $\begin{array}{c}0.230931 * * * \\
(0.077260)\end{array}$ & $\begin{array}{l}0.223643 * \\
(0.126558)\end{array}$ & $\begin{array}{c}0.227907 * * * \\
(0.077315)\end{array}$ \\
\hline Unemployment rate $(-1)$ & $\begin{array}{c}1.306414 * * * \\
(0.063242)\end{array}$ & $\begin{array}{c}1.256992 * * * \\
(0.048546)\end{array}$ & $\begin{array}{c}1.204606 * * * \\
(0.079522)\end{array}$ & $\begin{array}{c}1.256187 * * * \\
(0.048580)\end{array}$ \\
\hline Unemployment rate $(-2)$ & $\begin{array}{c}-0.440991 * * * \\
(0.067001)\end{array}$ & $\begin{array}{c}-0.381083 * * * \\
(0.055018)\end{array}$ & $\begin{array}{c}-0.408441 * * * \\
(0.090125)\end{array}$ & $\begin{array}{c}-0.380313 * * * \\
(0.055058)\end{array}$ \\
\hline Unemployment rate $(-3)$ & $\begin{array}{c}-0.132837 * * * \\
(0.040734)\end{array}$ & $\begin{array}{c}-0.122603 * * * \\
(0.037817)\end{array}$ & $\begin{array}{l}-0.093375 \\
(0.061947)\end{array}$ & $\begin{array}{c}-0.121656^{* * * *} \\
(0.037844)\end{array}$ \\
\hline Unemployment rate (-4) & $\begin{array}{c}0.875768 * * * \\
(0.047476)\end{array}$ & $\begin{array}{c}0.871230 * * * \\
(0.038072)\end{array}$ & $\begin{array}{c}0.921902 * * * \\
(0.062366)\end{array}$ & $\begin{array}{c}0.872629 * * * \\
(0.038100)\end{array}$ \\
\hline Unemployment rate (-5) & $\begin{array}{c}-1.156331 * * * \\
(0.083430)\end{array}$ & $\begin{array}{c}-1.102619 * * * \\
(0.055888)\end{array}$ & $\begin{array}{c}-1.054447 * * * \\
(0.091550)\end{array}$ & $\begin{array}{c}-1.102796^{* * * *} \\
(0.055928)\end{array}$ \\
\hline Unemployment rate (-6) & $\begin{array}{c}0.486954 * * * \\
(0.049373)\end{array}$ & $\begin{array}{c}0.427926 * * * \\
(0.044182)\end{array}$ & $\begin{array}{c}0.375938 * * * \\
(0.072375)\end{array}$ & $\begin{array}{c}0.426291 * * * \\
(0.044214)\end{array}$ \\
\hline Business cycle & $\begin{array}{c}-0.000829 * * * \\
(0.000299)\end{array}$ & $\begin{array}{c}-0.000462 * * * \\
(0.000174)\end{array}$ & $\begin{array}{l}-0.000282 \\
(0.000285)\end{array}$ & $\begin{array}{c}-0.000454 * * * \\
(0.000174)\end{array}$ \\
\hline Variance of inflation rate & $\begin{array}{c}1.424647 * * * \\
(0.3267655) \\
\end{array}$ & $\begin{array}{c}1.249204 * * * \\
(0.2829581) \\
\end{array}$ & $\begin{array}{l}1.211000 * * * \\
(0.4635107)\end{array}$ & $\begin{array}{l}1.242542 * * * \\
(0.2831600)\end{array}$ \\
\hline \multicolumn{5}{|c|}{ Statistics } \\
\hline Adjusted R-squared & 0.965464 & 0.807563 & 0.837720 & 0.801874 \\
\hline Durbin-Watson stat & 1.999780 & & & \\
\hline F-statistic & 818.6868 & & & \\
\hline Prob(F-statistic) & $<0.000001$ & & & \\
\hline
\end{tabular}

Note. 1$) * * *=$ p-value $<0,01 ; * *=0.01<$ p-value $<0.05 ; *=0.05<\mathrm{p}$-value $<0.10$.

2) Correlation $=$ Correlation between predicted values and observed values. 
Table 5B. Dependent variable: unemployment cycle long term (1959:04 - 2019:04)

\begin{tabular}{|c|c|c|c|c|}
\hline Variables & $\begin{array}{l}\text { MODEL } 1 \text { - OLS: HAC } \\
\text { standard errors \& } \\
\text { covariance } \\
\text { Coefficient (Std.Error) }\end{array}$ & $\begin{array}{l}\text { MODEL 2- Robust Least } \\
\text { Squares: (M-estimation) } \\
\text { Coefficient (Std.Error) }\end{array}$ & $\begin{array}{l}\text { MODEL 3 - Robust } \\
\text { Least Squares: } \\
\text { (S-estimation) } \\
\text { Coefficient (Std.Error) }\end{array}$ & $\begin{array}{l}\text { MODEL } 4 \text { - Robust } \\
\text { Least Squares: } \\
\text { (MM-estimation) } \\
\text { Coefficient (Std.Error) }\end{array}$ \\
\hline \multirow[t]{2}{*}{ Constant } & -0.013711 & $-0.038087 *$ & $-0.054849^{*}$ & $-0.037853^{*}$ \\
\hline & $(0.025793)$ & $(0.019708)$ & $(0.031411)$ & $(0.019687)$ \\
\hline Unemployment cycle & $1.303640 * * *$ & $1.253237 * * *$ & $1.178221 * * *$ & $1.254370 * * *$ \\
\hline $\mathrm{LT}(-1)$ & $(0.065797)$ & $(0.048652)$ & $(0.077543)$ & $(0.048601)$ \\
\hline Unemployment cycle LT & $-0.444773 * * *$ & $-0.383177 * * *$ & $-0.399490 * * *$ & $-0.384223 * * *$ \\
\hline$(-2)$ & $(0.064917)$ & $(0.054939)$ & $(0.087564)$ & $(0.054882)$ \\
\hline Unemployment cycle LT & $-0.132263 * * *$ & $-0.119743 * * *$ & -0.091847 & $-0.120880 * * *$ \\
\hline$(-3)$ & $(0.040457)$ & $(0.037799)$ & $(0.060245)$ & $(0.037759)$ \\
\hline Unemployment cycle LT & $0.874263 * * *$ & $0.876580 * * *$ & $0.922262 * * *$ & $0.874905 * * *$ \\
\hline$(-4)$ & $(0.047568)$ & (0.038079) & $(0.060692)$ & $(0.038040)$ \\
\hline Unemployment cycle LT & $-1.155024 * * *$ & $-1.104515^{* * *}$ & $-1.051586^{* * *}$ & $-1.104345^{* * *} *$ \\
\hline$(-5)$ & $(0.081822)$ & $(0.055889)$ & $(0.089078)$ & $(0.055831)$ \\
\hline Unemployment cycle LT & $0.490998 * * *$ & $0.427519 * * *$ & $0.375204 * * *$ & $0.429570 * * *$ \\
\hline$(-6)$ & $(0.490998)$ & $(0.044111)$ & $(0.070306)$ & $(0.044065)$ \\
\hline \multirow[t]{2}{*}{ Business cycle } & $-0.000841 * *$ & $-0.000469 * * *$ & -0.000442 & $-0.000477 * * *$ \\
\hline & $(0.000331)$ & $(0.000175)$ & $(0.000279)$ & $(0.000175)$ \\
\hline \multirow[t]{2}{*}{ Variance of inflation rate } & $1.329957 * * *$ & $1.178406^{* * *}$ & $1.211130 * * *$ & $1.183865 * * *$ \\
\hline & $(0.2901932)$ & $(0.2817797)$ & $(0.4491083)$ & $(0.2814848)$ \\
\hline \multicolumn{5}{|c|}{ Statistics } \\
\hline Adjusted R-squared & 0.963155 & 0.785162 & 0.811803 & 0.791655 \\
\hline Durbin-Watson stat & 1.989436 & & & \\
\hline F-statistic & 765.6200 & & & \\
\hline Prob(F-statistic) & $<0.00001$ & & & \\
\hline
\end{tabular}

Note. 1$) * * *=\mathrm{p}$-value $<0,01 ; * *=0.01<\mathrm{p}$-value $<0.05 ; *=0.05<\mathrm{p}$-value $<0.10$.

2) Correlation $=$ Correlation between predicted values and observed values.

Table 5C. Dependent variable: unemployment cycle short term (1959:04 - 2019:04)

\begin{tabular}{|c|c|c|c|c|}
\hline Variables & $\begin{array}{l}\text { MODEL } 1 \text { - OLS: HAC } \\
\text { standard errors \& } \\
\text { covariance } \\
\text { Coefficient (Std.Error) }\end{array}$ & $\begin{array}{l}\text { MODEL 2- Robust Least } \\
\text { Squares: (M-estimation) } \\
\text { Coefficient (Std.Error) }\end{array}$ & $\begin{array}{l}\text { MODEL 3 - Robust } \\
\text { Least Squares: } \\
\text { (S-estimation) } \\
\text { Coefficient (Std.Error) }\end{array}$ & $\begin{array}{l}\text { MODEL } 4 \text { - Robust } \\
\text { Least Squares: } \\
\text { (MM-estimation) } \\
\text { Coefficient (Std.Error) }\end{array}$ \\
\hline \multirow[t]{2}{*}{ Constant } & -0.013063 & $-0.037967 *$ & $-0.053709 *$ & $-0.037714^{*}$ \\
\hline & $(0.026473)$ & $(0.019619)$ & $(0.032042)$ & $(0.019601)$ \\
\hline Unemployment Cycle & $1.289447 * * *$ & $1.244662 * * *$ & $1.181190 * * *$ & $1.245569 * * *$ \\
\hline ST (-1) & $(0.064854)$ & (0.049104) & $(0.080196)$ & $(0.049059)$ \\
\hline Unemployment Cycle & $-0.442155 * * *$ & $-0.385314 * * *$ & $-0.396266 * * *$ & $-0.386188 * * *$ \\
\hline ST (-2) & $(0.064040)$ & $(0.055071)$ & $(0.089941)$ & $(0.055021)$ \\
\hline Unemployment Cycle & $-0.132575^{* * *}$ & $-0.121618^{* * *}$ & -0.097468 & $-0.122525 * * *$ \\
\hline ST (-3) & $(0.039965)$ & $(0.037801)$ & $(0.061737)$ & $(0.037767)$ \\
\hline Unemployment Cycle & $0.870785^{* * *}$ & $0.870860^{* * *}$ & $0.911667 * * *$ & $0.869417^{* * *}$ \\
\hline ST (-4) & $(0.047370)$ & $(0.038100)$ & $(0.062224)$ & $(0.038065)$ \\
\hline Unemployment Cycle & $-1.143819 * * *$ & $-1.094355^{* * *}$ & $-1.043925 * * *$ & $-1.094295 * * *$ \\
\hline ST (-5) & (0.080919) & $(0.056094)$ & $(0.091613)$ & $(0.056043)$ \\
\hline Unemployment Cycle & $0.489203 * * *$ & $0.431457^{* * *}$ & $0.381035 * * *$ & $0.433184 * * *$ \\
\hline ST $(-6)$ & $(0.045926)$ & $(0.044399)$ & $(0.072511)$ & $(0.044358)$ \\
\hline Business cycle & $\begin{array}{c}-0.000865 * * * \\
(0.000330)\end{array}$ & $\begin{array}{c}-0.000494 * * * \\
(0.000175)\end{array}$ & $\begin{array}{l}-0.000419 \\
(0.000285)\end{array}$ & $\begin{array}{c}-0.000501 * * * \\
(0.000175)\end{array}$ \\
\hline Variance of inflation & $1.277388^{* * *}$ & $1.110680^{* * * *}$ & $1.075570 * *$ & $1.116583^{* * * *}$ \\
\hline \multirow[t]{2}{*}{ rate } & $(0.3189134)$ & $(0.2813808)$ & $(0.4595490)$ & $(0.2811252)$ \\
\hline & & Statistics & & \\
\hline Adjusted R-squared & 0.959058 & 0.787597 & 0.810544 & 0.793332 \\
\hline Durbin-Watson stat & 1.997370 & & & \\
\hline F-statistic & 686.1724 & & & \\
\hline Prob(F-statistic) & $<0.000001$ & & & \\
\hline
\end{tabular}


Tables 6 and 7, based on a GMM system of two equations (equations 1 and 2), show three systems:

i) the first one shows the system of two equations so that Model 1A (Table 6) is connected with Model 1B (Table 7); ii) the second one shows the connection between Model 2A (Table 6) and Model 2B (Table 7) and iii) the last one shows the interaction between Model 3A (Table 6) and Model 3B (Table 7).

Table 6 shows that all the estimated coefficients are statistically significant at $1 \%$ level, except for the constant terms, which are not statically significant. One stands out that, the variance of real interest rate contributes to reducing the business cycle as expected. In other words, the greater the volatility of the real interest rate is, generating uncertainty and economic instability, the lower incentive for economic agents to make productive investments will be, as well as the lower incentive to obtain credit for consumption or production. Besides, the monetary policy indirectly affects the unemployment rate via business cycle.

In addition, the statistic $\mathrm{J}$ does not reject the hypothesis that the instruments are good and, in turn, the Stock-Yogo test, based on the Cragg-Donald F statistic, does not accept the null hypothesis that the instruments are weak. Hence, the instruments are good and valid.

Table 6. Estimation method: GMM (quarterly data from 1959:04 - 2019:04)

\begin{tabular}{|c|c|c|c|}
\hline & \multicolumn{3}{|c|}{ Dependent variables } \\
\hline & Model 1A & Model 2A & Model 3A \\
\hline & Business cycle & Business cycle & Business cycle \\
\hline \multirow[t]{2}{*}{ Constant } & 5.394881 & 4.855479 & 4.806069 \\
\hline & $(3.425289)$ & $(3.463795)$ & $(3.466833)$ \\
\hline \multirow[t]{2}{*}{ Business cycle $(-1)$} & $0.962542 * * *$ & $0.964478 * * *$ & $0.964974 * * *$ \\
\hline & $(0.021513)$ & $(0.021296)$ & $(0.021257)$ \\
\hline \multirow[t]{3}{*}{ Variance of real interest rate } & $-0.629696^{* * * *}$ & $-0.610645^{* * *} *$ & $-0.611200 * * *$ \\
\hline & $(0.234411)$ & $(0.229044)$ & $(0.231530)$ \\
\hline & \multicolumn{3}{|c|}{ Statistics } \\
\hline Adjusted R-squared & 0.736450 & 0.736324 & 0.736251 \\
\hline $\mathrm{J}-$ Statistics (p-value) & 0.131734 & 0.128546 & 0.126351 \\
\hline Stock-Yogo test (critical value at 5\%) & 20.48 & 20.48 & 20.48 \\
\hline Cragg-Donald F-stat: & 104.2293 & 104.2293 & 104.2293 \\
\hline
\end{tabular}

Note. 1$) * * *=$ p-value $<0,01 ; * *=0.01<$ p-value $<0.05 ; *=0.05<\mathrm{p}$-value $<0.10$.

2) Instrument specification: Variance of inflation rate (-1to-6), unemployment_rate*Variance of inflation rate, unemployment_rate*business cycle, Variance of real interest rate(-1to-4), real_gdp*real_interest_rate_cycle, @ trend, real_gdp, variance_funds_rate, nrou_long_term*real_interest_rate, nrou_long_term*real_interest_rate.

3) 235 observations.

The empirical results from Table 7 confirm the empirical results already presented regarding the variables business cycle and variance of inflation rate. In this sense, once more, there are empirical evidence regarding the robustness of the empirical results.

Table 7. Estimation method: GMM (Quarterly data from 1959:04 - 2019:04)

\begin{tabular}{|c|c|c|c|}
\hline & \multicolumn{3}{|c|}{ Dependent variables } \\
\hline & Model 1B & Model 2B & Model 3B \\
\hline & Unemployment rate & Unemployment rate long term & Unemployment rate Short term \\
\hline \multirow[t]{2}{*}{ Constant } & 0.093058 & $-0.035313 * * *$ & $-0.036172 * * *$ \\
\hline & $(0.069707)$ & $(0.013953)$ & $(0.014203)$ \\
\hline \multirow[t]{2}{*}{ Unemployment rate $(-1)$} & $1.563492 * * *$ & $1.561099 * * *$ & $1.555071 * * *$ \\
\hline & $(0.059068)$ & $(0.060563)$ & $(0.062984)$ \\
\hline \multirow[t]{2}{*}{ Unemployment rate $(-2)$} & $-0.494603 * * *$ & $-0.499102 * * *$ & $-0.485522 * * *$ \\
\hline & $(0.087298)$ & (0.086639) & $(0.090541)$ \\
\hline \multirow[t]{2}{*}{ Unemployment rate $(-3)$} & $-0.475331 * * *$ & $-0.466641 * * *$ & $-0.476219 * * *$ \\
\hline & $(0.087966)$ & $(0.086167)$ & $(0.087973)$ \\
\hline \multirow[t]{2}{*}{ Unemployment rate $(-4)$} & $0.932557 * * *$ & $0.928576^{* * * *}$ & $0.899678 * * *$ \\
\hline & $(0.080381)$ & $(0.080806)$ & $(0.081696)$ \\
\hline
\end{tabular}




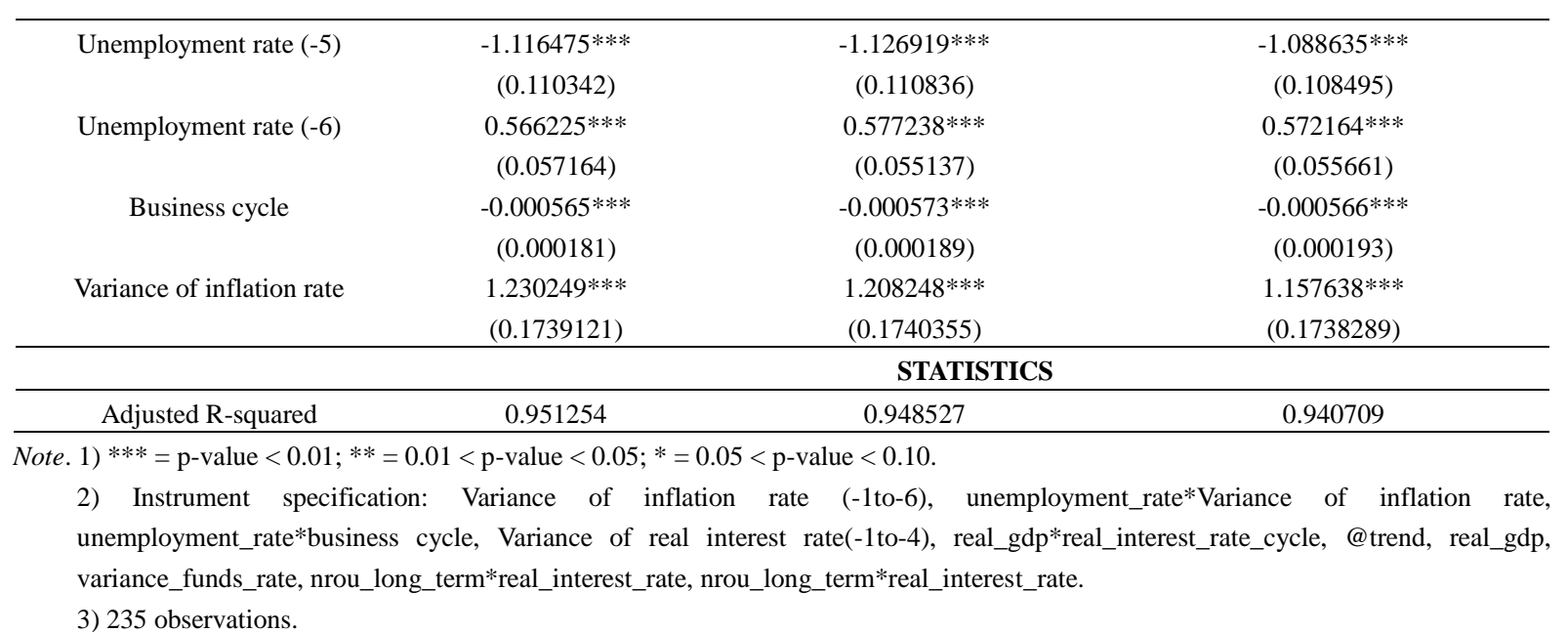

The first system is shown by Model 1A in Table 6 and by model 1B in Table 7. Model 1B shows the direct effect of the business cycle on unemployment, with the estimated coefficient value of -0.000565 . Nevertheless, based on Model 1A, the indirect effect displays that variance of real interest rate affects the business cycle with the estimated coefficient of -0.629696 , and in turn affects the unemployment rate (Model 1B). In this case, the final indirect effect is calculated as $(-0.000565) *(-0.629696)$, which results in a value of 0.000356 , according to Moreira et al (2016). The indirect effect from the variance of real interest rate on the unemployment rate, via business cycle, is positive as expected. The higher the variance of real interest rate is, the higher the unemployment rate will be. The indirect effect for Models $2 \mathrm{~A}$ and $2 \mathrm{~B}$, as well as $3 \mathrm{~A}$ and $3 \mathrm{~B}$ are similar.

\section{Discussion}

Since correlation does not mean causality, this article asks, firstly, whether there is a one-way causality, so that unemployment rate causes inflation rate, as the original Phillips curve implicitly assumes. The empirical results, based on Granger causality tests, display that there is a two-way causality between them, based on the American economy from 1959:04 to 2019:04. The same result is confirmed when short and long-term unemployment cycles are related to the inflation rate. But, so what? What can public policy make out of these conclusions reached? At the very least, the fundamentals of the original Phillips curve must be questioned.

Considering the mutual causal relationship between inflation and unemployment, new possibilities of investigation are opened between these two variables. Firstly, this article shows that the variance of inflation rate causes the unemployment variables, but the opposite does not occur. Besides, the empirical results show that the variance of inflation rate has a direct and positive effect on the three dependent variables. In other words, the variance of inflation rate increases the unemployment rate and the unemployment cycle variables. This means that there is no trade-off between variance of inflation rate and the three variables associated to unemployment.

Secondly, there is a one-way causality from business cycle to unemployment rate, as well as unemployment cycles of long and short term. In this context, the estimated coefficient regarding business cycle is negative, showing that an excess of demand reduces unemployment rate variables. This is one more interesting result, because generally these variables are considering proxies between them. This empirical result suggests that the business cycle precedes the unemployment and that, therefore, the variables of unemployment react later to the business cycle effect. Hence, the unemployment variables adjust more slowly, possibly due to greater rigidity in the labor market.

At last, the variance of real interest rate contributes to reducing the business cycle as expected. Hence, the monetary policy indirectly affects the unemployment rate via business cycle. The indirect effect from the variance of real interest rate on the unemployment rate via business cycle is positive as expected. The higher the variance of real interest rate is, the higher the unemployment rate will be. The results are similar considering the unemployment cycle variables.

\section{Acknowledgments}

The authors are grateful for the support of CNPq and CAPES.

\section{References}

Barro, R. J. (1976). Rational Expectations and the Role of Monetary Policy. Journal of Monetary Economics, 
2(January), 1-32. https://doi.org/10.1016/0304-3932(76)90002-7

Barro, R. J. (1977). Unanticipated Money Growth and Unemployment in the United States. American Economic Review, 67(March), 101-115.

Cragg, J. G., \& Donald, S. G. (1993). Testing Identifiability and Specification in Instrumental Variables Models. Econometric Theory, 9, 222-240. https://doi.org/10.1017/S0266466600007519

Friedman, M. (1968). The Role of Monetary Policy. American Economic Review, 58, 1-17.

Granger, C. W. J. (1969). Investigating Causal Relations by Econometric Models and Cross-Spectral Methods. Econometrica, 37, 424-438. https://doi.org/10.2307/1912791

Hayek, F. A. (1979). Unemployment and Monetary Policy: Government as Generator of the Business Cycle. Editora: Cato Inst.

Hayek, F. A. (2011). Desemprego e Política Monetária. Instituto Ludwig von Mises, São Paulo.

Hsiao, C. (1997a). Statistical properties of the two-stage last squares estimator under cointegration. The Review of Economic Studies, 64, 385-398. https://doi.org/10.2307/2971719

Hsiao, C. (1997b). Cointegration and dynamic simultaneous equations models. Econometrica, 65, 647-670. https://doi.org/10.2307/2171757

Lucas Jr., R. E. (1972a). Econometric Testing of the Natural Rate Hypothesis. In R. E. Lucas Jr. (Ed.), Studies in Business-Cycle Theory (pp. 90-103). Oxford: Basil Blackwell.

Lucas Jr., R. E. (1972b). Expectations and the Neutrality of Money. Journal of Economic Theory, 4(2), 103-124. https://doi.org/10.1016/0022-0531(72)90142-1

McCallum, B. T. (1982). Macroeconomics after a decade of rational expectations: Some critical issue. Economic Review, 2-12. https://doi.org/10.3386/w1050

Moreira, M. J. (2001). Tests with Correct Size When Instruments Can Be Arbitrarily Weak, MIMEO.

Moreira, T. B. S., Tabak, B. M., Mendonça, M. J., \& Sahsida, A. (2016). An Evaluation of the Non-Neutrality of Money. Plos One, 1-20. https://doi.org/10.1371/journal.pone.0145710

Muth, J. A. (1961). Rational Expectations and the Theory of Price Movements. Econometrica, 29(6), 315-35. https://doi.org/10.2307/1909635

Newey, W., \& West, K. (1987a). Hypothesis testing with efficient method of moments estimation. International Economics Review, 28, 777-787. https://doi.org/10.2307/2526578

Newey, W., \& West, K. (1987b). A simple positive semi-definite, heteroskedasticity and autocorrelation consistent covariance matrix. Econometrica, 55, 703-708. https://doi.org/10.2307/1913610

Peter, H., Frederic, S. M., \& Amir, S. (2020). Prospects for inflation in a high pressure economy: Is the Phillips curve dead or is it just hibernating? Research in Economics, 74(1), 26-62. https://doi.org/10.1016/j.rie.2019.11.004

Phelps, E. S. (1995). The Origins and Further Development of the Natural Rate of Unemployment. In R. Cross (Ed.), The Natural Rate of Unemployment: Reflections on 25 years of the Hypothesis. Cambridge: Cambridge University Press. https://doi.org/10.1017/CBO9780511559631.003

Phillips, A. W. (1958). The Relation Between Unemployment and the Rate of Change of Money Wage Rates in the United Kingdom, 1861-19571. Economica, 25(100), 283-299. https://doi.org/10.1111/j.1468-0335.1958.tb00003.x

Samuelson, P. A., \& Solow, R. M. (1960). Analytical Aspects of Anti-Inflation Policy. American Economic Review, 50(2), 177-194.

Sargent, T. J. (1973). Rational Expectations, the Real Rate of Interest, and the Natural Rate of Unemployment. Brookings Papers on Economic Activity, (2), 429-472. https://doi.org/10.2307/2534097

Stock, J. H., \& Watson, M. W. (2001). Vector Autoregressions. Journal of Economic Perspectives, 15(4), 101-115. https://doi.org/10.1257/jep.15.4.101

Stock, J. H., \& Yogo M. (2005). Testing for Weak Instruments in Linear IV Regression. In D. W. Andrews, \& J. H. Stock (Eds.), Identification and Inference for Econometric Models: Essays in Honor of Thomas Rothenberg (pp. 80-108). Cambridge University Press. https://doi.org/10.1017/CBO9780511614491.006 
Stock, J. H., Wright, J. H., \& Yogo, M. (2002). A Survey of Weak Instruments and Weak Identification in Generalized Method of Moments. Journal of Business \& Economic Statistics, 20(4), 518-529. https://doi.org/10.1198/073500102288618658

Taylor, J. B. (1993). Discretion Versus Policy Rules in Practice. Carnegie-Rochester Conference Series on Public Policy, 39, 195-214. https://doi.org/10.1016/0167-2231(93)90009-L

\section{Copyrights}

Copyright for this article is retained by the author(s), with first publication rights granted to the journal.

This is an open-access article distributed under the terms and conditions of the Creative Commons Attribution license (http://creativecommons.org/licenses/by/4.0/). 